\title{
SEISMIC ANAL YSIS OF UNSYMMETRICAL BUILDING WITH DIFFERENT BRACING SYSTEMS
}

\author{
Priyanka.T ${ }^{1}$, Shilpa.V.B ${ }^{2}$ \\ ${ }^{1}$ PG Student, Department of Civil Engineering, Sambhram Institute of Technology, Bengaluru, Karnataka, India \\ ${ }^{2}$ Assistant Professor, Department of Civil Engineering, Sambhram Institute of Technology, Bengaluru, Karnataka, \\ India
}

\begin{abstract}
Earthquake leads to ground shaking and collapse of structure in all direction due to base movement of the building with the ground. In the present days, unsymmerical building plans are repeatedly constructed for aesthetic purpose. These building includes discontinuity in mass, geometry and stiffness of structure, which leads to destruction during earthquake. In the current work an endeavour has been made to study the dynamic behaviour of regular building in comparison with irregular buildings with different bracing system using IS 1983-2002 (Part 1) code recommended response spectrum method. Analysis of building has been carried out using ETABS software.
\end{abstract}

Keywords: Bracing System, Equivalent Static Method, Response Spectrum Method, Unsymmetrical Building.

\section{INTRODUCTION}

Dynamic loads acting on the structure are responsible for the major structural collapse during earthquake. Now a days, most of the structures are concerned with architectural importance and it is extremely not viable to plan with regular shapes. These irregularities are liable for structural collapse of building under the action of dynamic loads, consequently there is a need for extensive research for achieving ultimate performance of structure even with deuced configuration.

\subsection{Equivalent Static Analysis}

The seismic design of buildings includes dynamic nature of the loads. This method accounts for only one mode of vibration in each direction during earthquake. This method is suitable for the analysis of simpler and regular buildings.

\subsection{Response Spectrum Analysis}

A response spectrum is a graphical represention of single degree freedom system with varying natural frequency and damping under the action of dynamic loads during earthquake. In this method, muitiple modes of vibrations of structures are considered. This analysis is carried out to according to IS 1893-2002(Part I) code.

\section{OBJECTIVES OF STUDIES}

$>$ To analyze the structure as per IS 1893-2002(Part I) code and to study response of braced and unbraced for symmetrical and unsymmerical buildings.

$>$ To study methods of seismic analysis and to study seismic analysis of frame by ETBS version 9.7.4.

\section{MODELING AND ANALYSIS OF BUILDING}

For the analysis work, 32 models of high rise $\mathrm{RC}$ frame building $(\mathrm{G}+19)$ storey for soft soil of regular shape, Cshape, U-shape and L- shape with bare frame, X-bracing, Vbracing and $\mathrm{K}$ - bracing are made to known the practical behaviour of building during earthquake. The parameters considered are lateral displacement, story drift, time period and base shear.

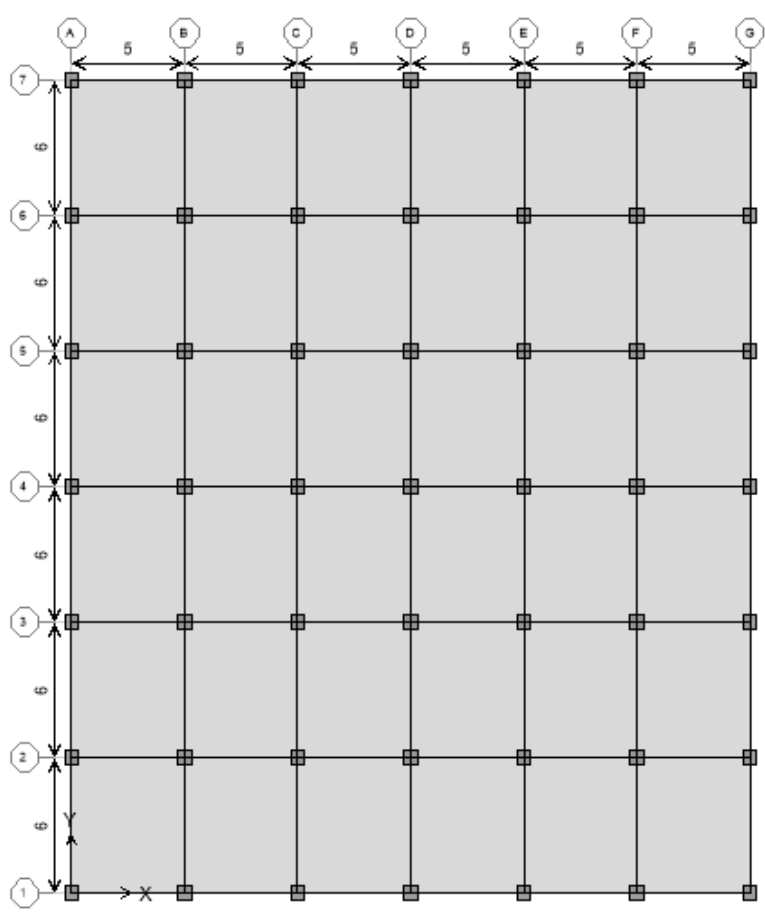

Fig 3.1. Plan of a structure 


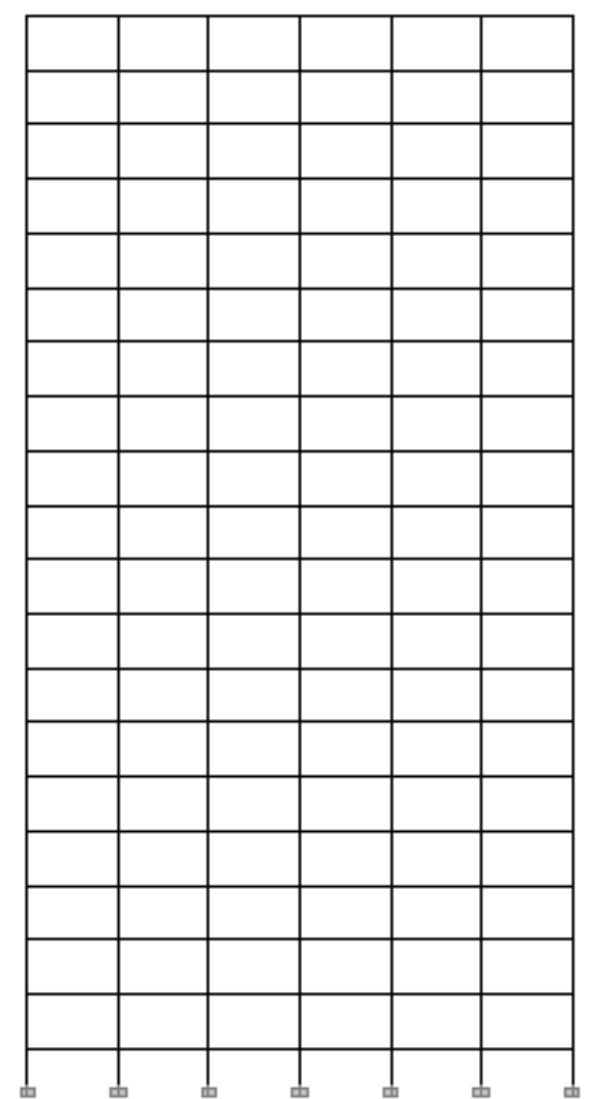

Fig.3.2. Elevation of Unbraced Structure

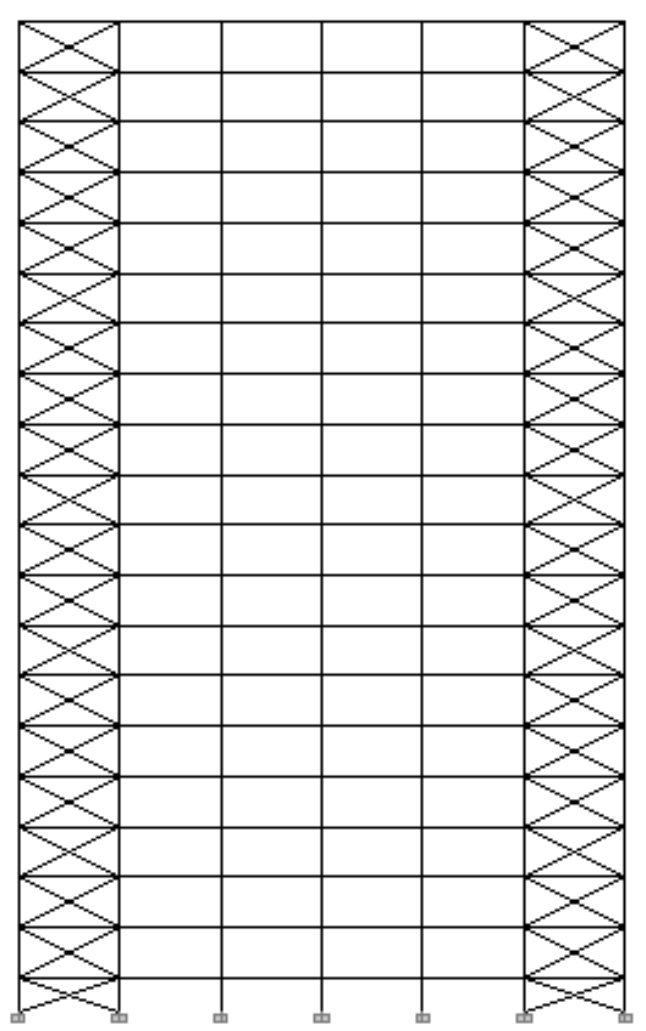

Fig.3.3. Elevation of X-Braced Structure

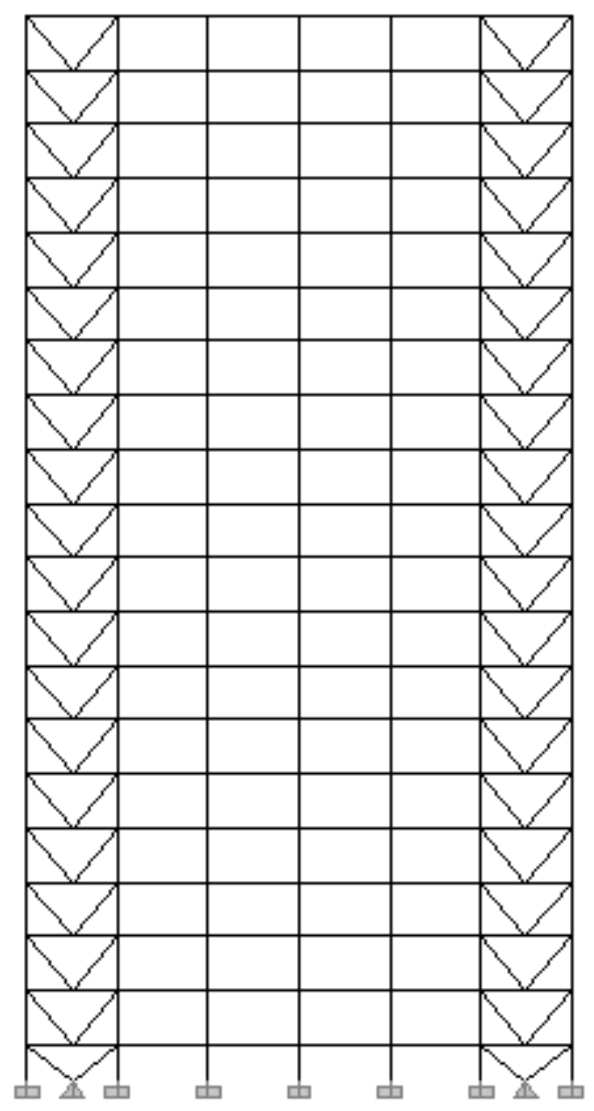

Fig.3.4. Elevation of V- Braced Structure

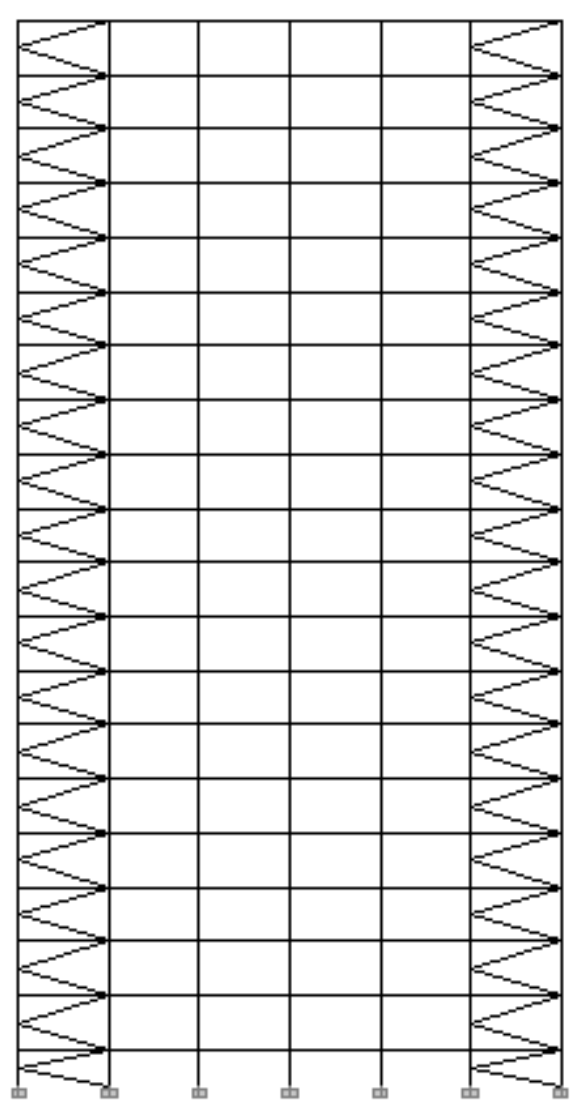

Fig.3.5. Elevation of K- Braced Structure 


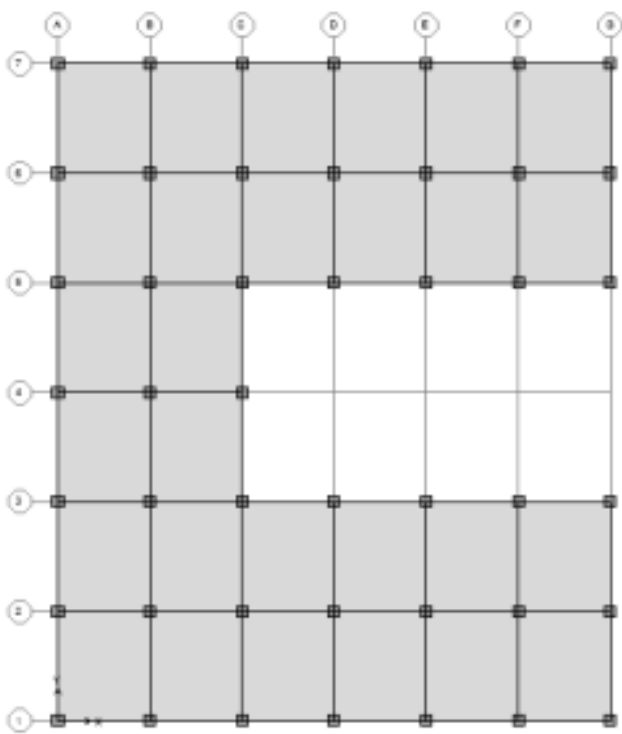

Fig.3.6. Plan of C - shaped structure

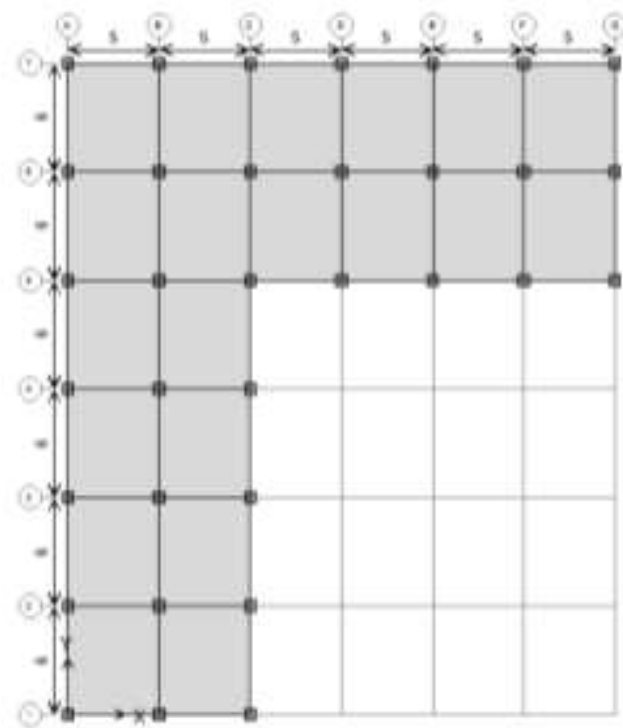

Fig.3.7. Plan of L - shaped structure

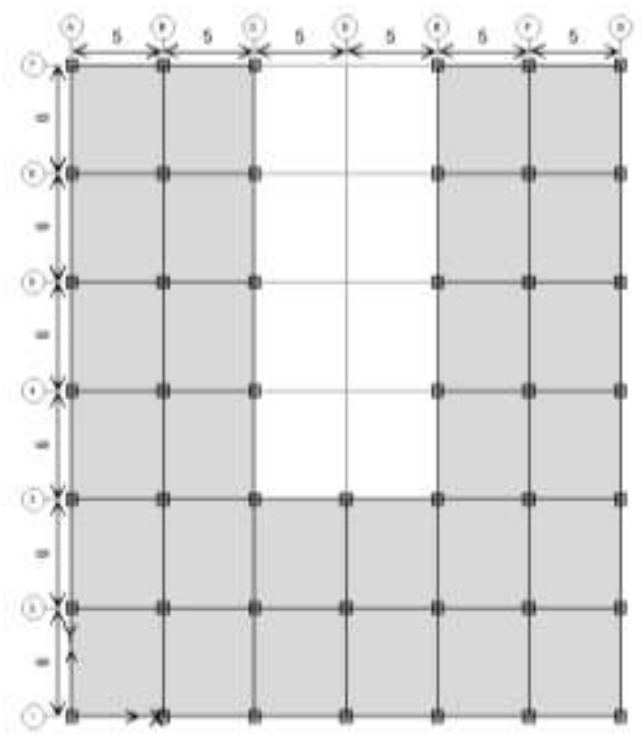

Fig.3.7. Plan of U - shaped structure

\section{SELECTION OF STRUCTURE}

Table 1: Modelling Information

\begin{tabular}{|c|c|}
\hline \multicolumn{2}{|l|}{ 1) Grid Data } \\
\hline a) Grid Spacing & $\begin{array}{l}\text { Non uniform - } 5 \text { meter - X } \\
\text { and } 6 \text { meter - Y direction. }\end{array}$ \\
\hline b) Total Dimension & $\begin{array}{l}30 \mathrm{~m}-\mathrm{X} \text { and } 36 \mathrm{~m}-\mathrm{Y} \\
\text { direction }\end{array}$ \\
\hline c) Grid Height & $\begin{array}{l}\text { Uniform - } 3 \text { meters, At } \\
\text { base }-2 \mathrm{~m}\end{array}$ \\
\hline d) No. Of Stories & $(\mathrm{G}+19)$ \\
\hline e) Building Height & $59 \mathrm{~m}$ \\
\hline \multicolumn{2}{|l|}{ 2) Material Properties } \\
\hline a) Grade of Concrete & $\mathrm{M}_{35}$ \\
\hline b) Grade of Steel & $\mathrm{Fe}-500$ \\
\hline c) Poisson s ratio & 0.2 \\
\hline \multicolumn{2}{|l|}{ 3) Frame Properties } \\
\hline a) Type of frame & $\begin{array}{l}\text { Special RC moment resisting } \\
\text { frame fixed at the base }\end{array}$ \\
\hline b) Size of beam & $(300 \times 600) \mathrm{mm}$ \\
\hline c) Size of column & $\begin{array}{l}(750 \mathrm{X} 750) \mathrm{mm}\left(\text { From }^{1 \mathrm{st}} \text { to }\right. \\
\left.10^{\text {th }} \text { story }\right)\end{array}$ \\
\hline d) Size of column & $\begin{array}{l}(600 \times 600) \mathrm{mm} \text { ( From } 11^{\text {th }} \text { to } \\
\text { to } 20^{\text {th }} \text { story) }\end{array}$ \\
\hline e) Bracing: & ISA (200X200X25) \\
\hline $\begin{array}{l}\text { f) Grade of Steel } \\
\text { for Bracings }\end{array}$ & Fe- 345 \\
\hline g) Thickness of Slab & $175 \mathrm{~mm}$ \\
\hline \multicolumn{2}{|l|}{ 4) Static Loads } \\
\hline a) Live load & $3 \mathrm{KN} / \mathrm{m}^{2}$ \\
\hline b) Floor finish & $1.5 \mathrm{KN} / \mathrm{m}^{2}$ \\
\hline c) Wall load & $\begin{array}{l}11.04 \mathrm{KN} / \mathrm{m}^{2} \text { (Considered } \\
\text { only for peripheral beams } \\
\text { of the building) }\end{array}$ \\
\hline \multicolumn{2}{|l|}{ 5) Seismic Definition } \\
\hline a) Earthquake Zone : & IV \\
\hline b) Damping ratio: & $5 \%$ \\
\hline c) Importance factor: & 1 \\
\hline d) Type of soil: & Medium Soil \\
\hline $\begin{array}{l}\text { e) Respose Reduction } \\
\text { Factor: }\end{array}$ & 5 \\
\hline f) Time Period : & 1.59 ( User Defined) \\
\hline
\end{tabular}

\section{RESULTS AND DISCUSSIONS}

\subsection{Lateral Displacement}

It can be ascertained from the graph that the lateral displacement have been decreased significantly for X-type of bracing system, while maximum displacement is observed for bare frame ( i.e. without any bracing system).The displacement are reduced sequentially for $\mathrm{K}$ bracing and V-bracing. These patterns are ascertained due to increased stiffness provided by the respective bracings. 


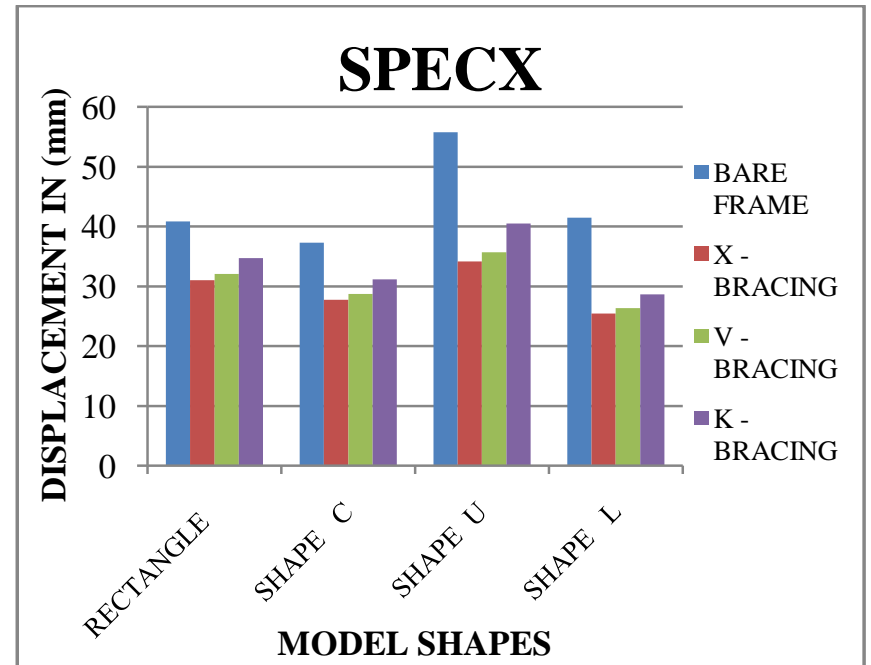

Fig.5.1.Graph of Lateral Displacement (mm) in X Direction

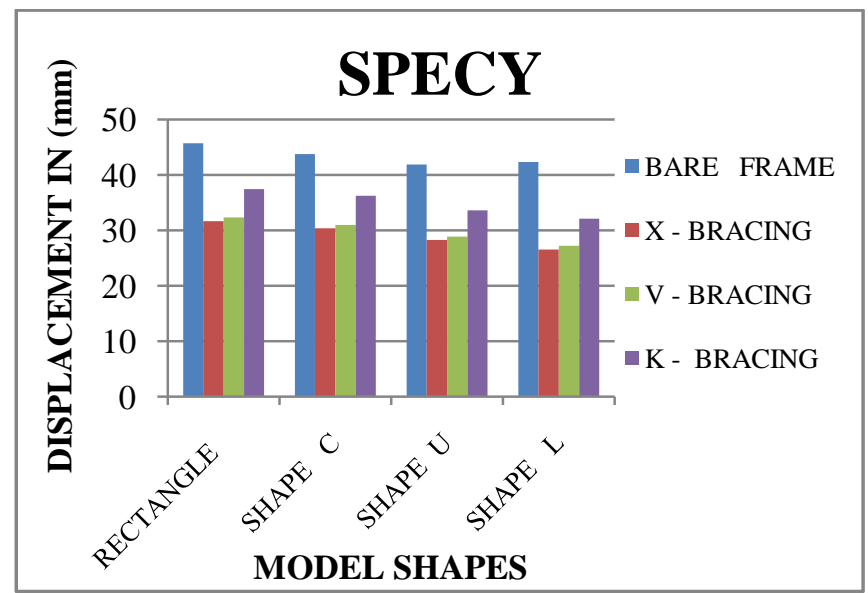

Fig.5.2.Graph of Lateral Displacement (mm) in Y Direction

\subsection{Storey Drift}

It is ascertained that the storey drifts are significantly reduced for X-type of bracing systems, while storey drifts are maximum for bare frames.

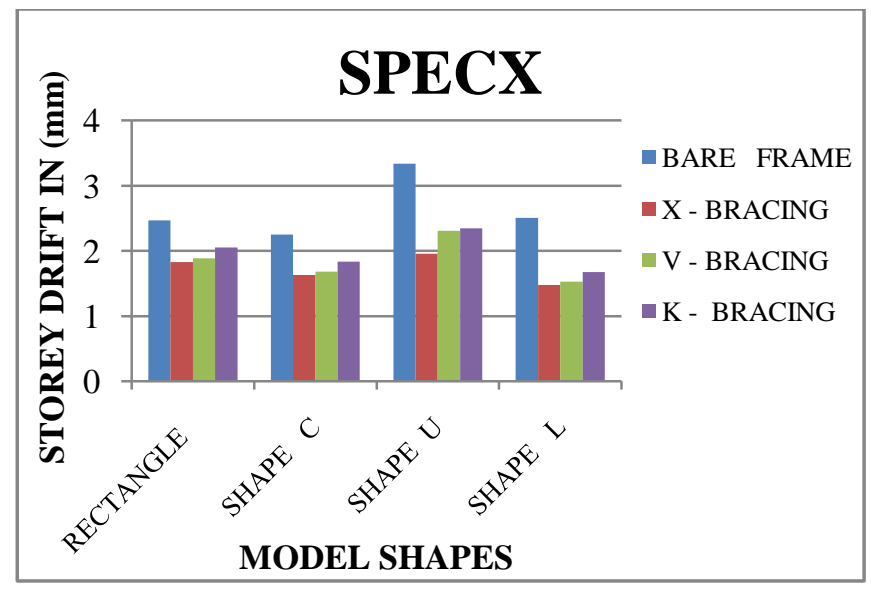

Fig.5.3. Graph of Storey Drift Displacement (mm) in XDirection

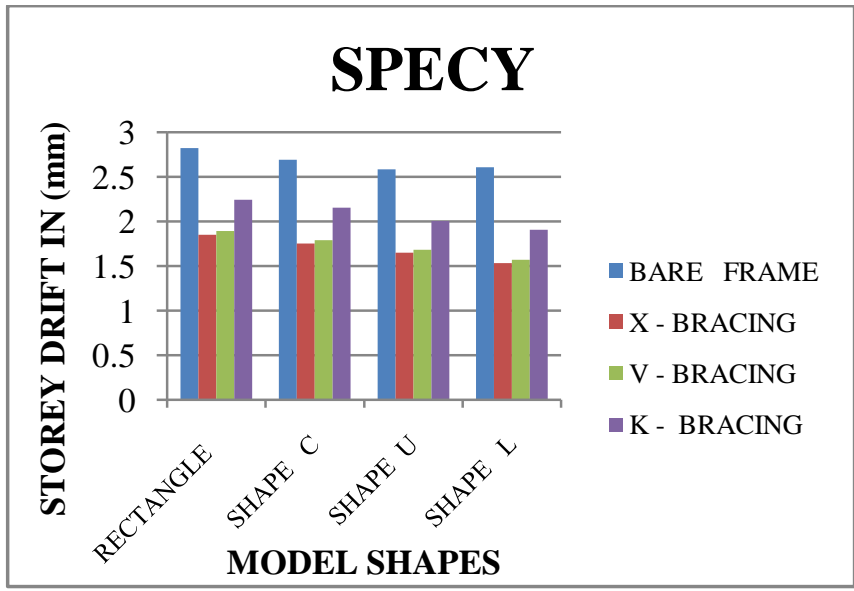

Fig.5.4. Graph of Storey Drift Displacement (mm) in YDirection

\subsection{Base Shear}

There is a significant increase in the base shear of the buildings by inclusion of bracing systems and it is maximum for $\mathrm{X}$ - type of bracing systems.

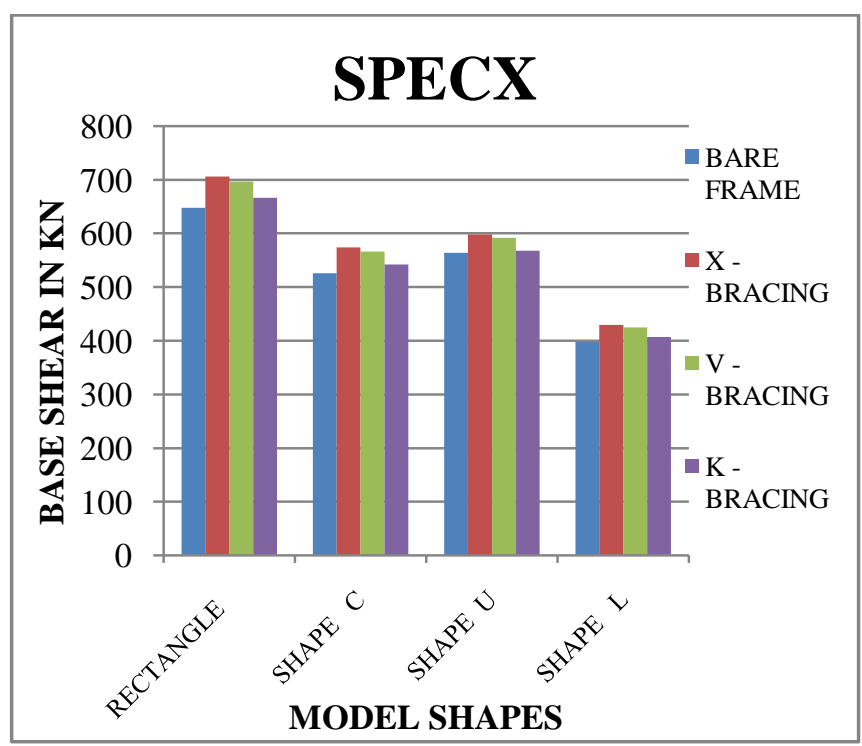

Fig.5.5. Graph of Base Shear $(\mathrm{KN})$ in $\mathrm{X}$ - Direction

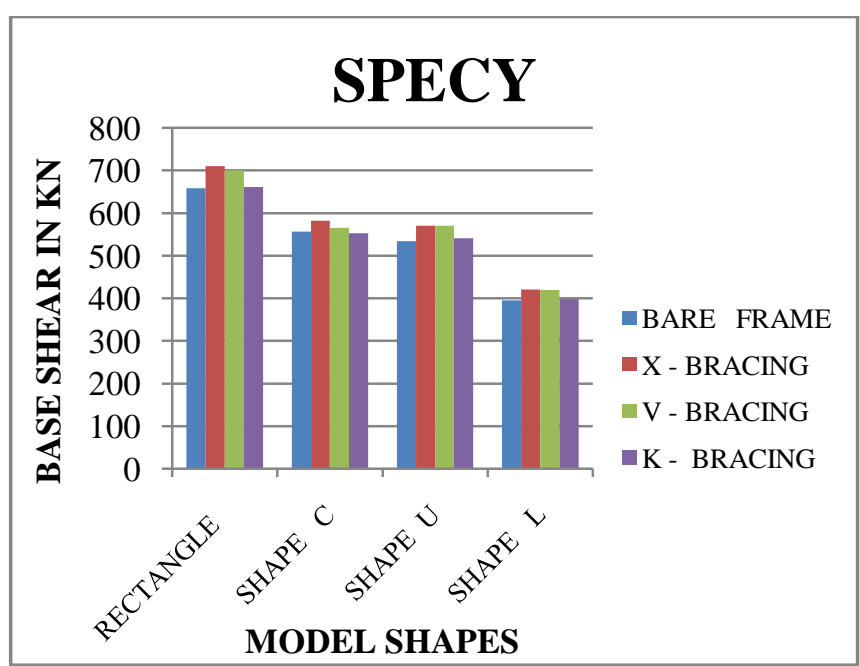

Fig.5.6. Graph of Base Shear $(\mathrm{KN})$ in $\mathrm{Y}$ - Direction 


\subsection{Time Period}

It is observed that the time period is reduced by introducing bracing systems into the buildings.

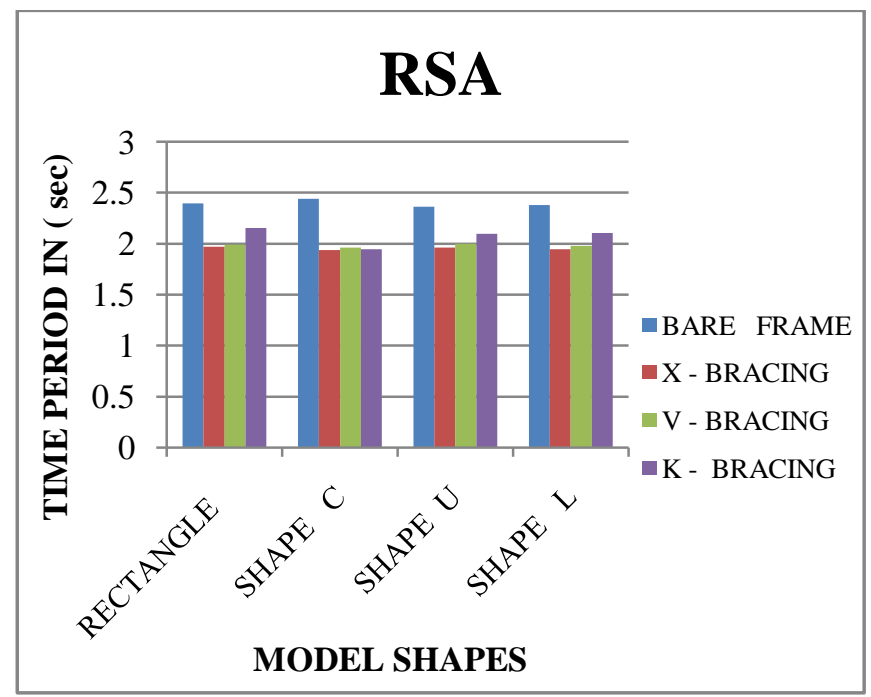

Fig.5.5. Graph of Time Period in (sec)

\section{CONCLUSION}

The following conclusions are extracted based on analysis.

$>$ Steel bracings can be used significantly to reduce lateral loads.

$>$ Introduction of irregularities to regular buildings will affects the performance of the buildings.

$>$ Introduction of steel bracings will not account for total weight of the existing building significantly.

$>$ Overall performance of X-type bracing is significant when compared with $\mathrm{K}$ and $\mathrm{V}$ type bracings.

\section{REFERENCES}

[1] Nitin Bhojkar ,Mahesh Bagade ,'Seismic Evaluation of High - rise Structure by Using Steel Bracing System", IJISET Volume 2,Issue 3, March 2015.

[2] Ravikanth Chittiprolu, Ramancharla Pradeep Kumar, ," Significance of Shear wall in High rise Irregular Buildingse, IJEAR Volume 4, Issue SpL-2, Jan - June 2014.

[3] Varsha R. Harne (2014),"Comparative Study of Strength of RC Shear wall at different location of Multistoried Residential Building", International Journal of Civil Engineering Research ISSN 2278-3652,Volume 5, Number 4 (2014), pp. 391-400.

[4] Shaikh Abdul Aijaj Abdul Rahman (2013), "Seismic Response of Vertically Irregular RC Frame with Stiffness Irregularity at Fourth Floor", International Journal of Emerging Technology \& Advanced Engineering ISSN 2250-2459, Volume 3, Issue 8 (2013).

[5]. Amin Alavi, P. Srinivasa Rao., Effect of Plan Irregular RC Buildings in High Seismic Zone. Aust. J. Basic \& Appl. Sci., 7(13): 1-6, 2013.

[6]. Bureau of Indian Standards: IS-1893, part 1 (2002), Criteria for Earthquake Resistant Design of Structures: Part 1 General provisions and Buildings, New Delhi, India.

[7]. Bureau of Indian Standards: IS-875, part 1 (1987), Dead Loads on Buildings and Structures, New Delhi, India. 